\title{
Lehmien ylläpitotarpeen ja muuntokelpoisen energian käytön tehokkuuden perinnöllinen vaihtelu maidontuotannossa
}

\author{
Marja-Liisa Sevón-Aimonen ${ }^{1)}$, Mike Coffey ${ }^{2)}$,Martin Lidauer ${ }^{1)}$,Tianhai Yan ${ }^{3)}$ \\ ${ }^{1)}$ Luonnonvarakeskus (Luke), Vihreä teknologia, etunimi.sukunimi@luke.fi \\ ${ }^{2)}$ Scotland's Rural College, UNITED KINGDOM \\ ${ }^{3)}$ Agrifood-Food and Biosciences Institute, UNITED KINGDOM
}

\section{TIIVISTELMÄ}

Tutkimus kuului osana EU:n rahoittamaan Solid (Sustainable Organic and Low Input Dairying) hanketta ja työpaketin tarkennettuna tavoitteena oli selvittää ylläpitotarpeen ja muuntokelpoisen energian käytön tehokkuuden perinnöllistä vaihtelua maidontuotannossa. Aineiston lähtömateriaalina käytettiin 17 vuoden aikana tehdyistä metaboliakammiotutkimuksista koottua aineistoa (AFBI Hillborough), joka sisälsi yhteensä 734 havaintoa 296 holstein-friisiläislehmältä. Varianssikomponenttien estimointia varten aineistosta poimittiin eläimet, joilla oli polveutumistiedot. Mukaan hyväksyttiin vain sellaiset yksittäiset kokeet, joissa oli vähintään kolme polveutumistietoehdot täyttävää lehmää. Lisäksi lehmien isiltä vaadittiin vähintään kaksi ehdot täyttävää tytärtä. Lopullinen analyysiaineisto sisälsi 469 havaintoa kaikkiaan 161 lehmältä, jotka olivat 64 sonnin jälkeläisiä. Sukulaisuusaineisto sisälsi 1297 eläintä. Varsinaiset tutkittavat muuttujat olivat muuntokelpoisen energian tarve ylläpitoon $\left(\mathrm{ME}_{\mathrm{m}}\right)$ ja muuntokelpoisen energian käytön tehokkuus maidontuotannossa $\left(\mathrm{k}_{1}\right)$. Nämä arvot oli laskettu lehmäkohtaisesti metaboliakammiotulosten perusteella. Lisäksi analysoitiin energiakorjatun maidon tuotanto muuntokelpoisen energian syöntiä kohti (ECE) sekä elopaino (LWT) vertailuominaisuutena. Varianssikomponentit estimointiin eläinmallilla DMU-ohjelmistoa ja Restricted Maximum Likelihood (REML)-menetelmää käyttäen. Malli sisälsi kokeen numeron sekä luokitellun karkearehun osuuden kiinteinä tekijöinä ja additiivisen eläintekijän, pysyvän eläintekijän ja jäännöstekijän satunnaisina. Varianssikomponenteista laskettiin eläinkohtaisen pysyvän ympäristövarianssin osuus kokonaisvarianssista (c2) ja periytymisaste (h2) keskivirheineen (SE). Muuttujien $\mathrm{ME}_{\mathrm{m}} \mathrm{ja} \mathrm{k}_{\mathrm{l}} \mathrm{c}^{2}$ ja $\mathrm{h}^{2}$ estimaatit eivät eronneet nollasta. Sekä ECE:n $(0,09 \pm 0,04)$ että LWT:n $(0,25 \pm 0,23) \mathrm{c}^{2}$ poikkesivat tilastollisesti merkitsevästi nollasta. ECE:ssä $(0,05 \pm 0,09)$ näytti olevan perinnöllistä vaihtelua vaikkakaan $\mathrm{h}^{2}$ poikennut tilastollisesti nollasta. ECE:n erona $\mathrm{ME}_{\mathrm{m}^{-}}$ja $\mathrm{k}_{\mathrm{l}}$-muuttujiin on, että elopainon muutosta ei ole muuttujaa laskettaessa otettu huomioon. Myös vertailuominaisuutena olleen LWT:n $(0,50 \pm 0,23)$ h2 poikkesi tilastollisesti nollasta ja oli ominaisuudelle yleensä saatujen estimaattien tasoa. Vaikka aineisto oli laajuudeltaan huomattava lehmien energiametaboliatutkimuksen alalla, oli eläinmäärä liian pieni varianssikomponenttien luotettavaan estimointiin varsinkin heikosti periytyvissä ominaisuuksissa. Tämän aineiston perusteella ei muuntokelpoisen energian tarpeessa ylläpitoon tai energian käytön tehokkuudessa maidontuotantoon ilmennyt perinnöllistä vaihtelua, joka tarkoittaa ettei näiden ominaisuuksien kehittäminen jalostusvalinnalla olisi mahdollista. Energiakorjatun maidon tuotannossa muuntokelpoisen energian syöntiä kohden näytti kuitenkin olevan viitteitä perinnöllisestä vaihtelusta.

Asiasanat: perinnölliset tunnusluvut, maidontuotanto, ylläpitotarve, tehokkuus 


\section{JOHDANTO}

Tutkimus kuului osana EU:n rahoittamaan Solid (Sustainable Organic and Low Input Dairying) hanketta ja työpaketin tarkennettuna tavoitteena oli selvittää ylläpitotarpeen ja muuntokelpoisen energian käytön tehokkuutta maidontuotannossa eri roduilla. Koska muilta kuin holstein-friisiläisiltä havaintoja oli vähän, tarkennettuna tavoitteena oli estimoida periytymisasteet tutkittaville muuttujille.

\section{AINEISTO JA MENETELMÄT}

Aineiston lähtömateriaalina käytettiin 17 vuoden aikana tehdyistä metaboliakammiotutkimuksista koottua aineistoa (AFBI Hillborough). Metaboliakammiotuloksia oli enemmänkin, mutta analyysiaineistoa varten rajattiin mukaan holstein-friisiläisrotuiset lehmät eli yhteensä 734 havaintoa 296 lehmältä. Varianssikomponenttien estimointia varten aineistosta poimittiin vain sellaiset eläimet, joilla oli polveutumistiedot. Mukaan hyväksyttiin ainoastaan sellaiset yksittäiset kokeet, joissa oli vähintään kolme polveutumistietoehdot täyttävää lehmää. Lisäksi lehmien isiltä vaadittiin vähintään kaksi ehdot täyttävää tytärtä. Lopullinen analyysiaineisto sisälsi 469 havaintoa kaikkiaan 161 lehmältä, jotka olivat 64 sonnin jälkeläisiä. Sukulaisuusaineisto sisälsi 1297 eläintä.

Varsinaiset tutkittavat muuttujat olivat muuntokelpoisen energian tarve ylläpitoon $\left(\mathrm{ME}_{\mathrm{m}}\right)$ ja muuntokelpoisen energian käytön tehokkuus maidontuotannossa $\left(\mathrm{k}_{\mathrm{l}}\right)$. Yksilöllinen ylläpitotarve $\mathrm{ME}_{\mathrm{m}}(\mathrm{MJ} / \mathrm{pv})$ oli estimoitu lämmöntuotannosta $(\mathrm{HP}, \mathrm{MJ} / \mathrm{pv}$, josta oli vähennetty energiahävikki muuntokelpoisen energian hyväksikäytöstä maidontuotantoon, painon muutos ja tiineyden vaihe. Lehmän yksilöllinen $\mathrm{k}_{1}$ laskettiin jakamalla nollaenergiataseeseen korjattu maidon energiamäärä (AFRC 1993) ME saannin ja ylläpitoenergiatarpeen $\left(\mathrm{ME}_{\mathrm{m}}\right)$ erotuksella. Lisäsi tarkasteltiin energiakorjatun maitotuotosta jaettuna muuntokelpoisen energian syönnillä (ECE) sekä elopainoa (LWT).

Varianssikomponentit estimoitiin käyttäen DMU-ohjelmistoa ja AI-REML menetelmää (Madsen \& Jensen, 2013). Käytetty tilastollinen malli oli:

$$
\begin{aligned}
& y_{i j k l m}=\operatorname{Exp}_{i}+F P C_{j}+L_{e h m a ̈}+E_{l a ̈ i n}^{m}+e_{i j k l m} \text {, jossa } \\
& y_{\mathrm{ijklm}}=\text { havainto }\left(\mathrm{ME}_{\mathrm{m}}, \mathrm{k}_{\mathrm{l}}, \mathrm{ECE}, \mathrm{LWT}\right) \\
& \operatorname{EXP}_{\mathrm{i}}=\text { kiinteä koevaikutus } \mathrm{i}, \mathrm{i}=1 \ldots 24 \\
& F P C_{j}=\text { kiinteä luokiteltu karkearehun osuus j, j=1 ...8 } \\
& \text { Lehmä }=\text { eläimen pysyvä ympäristövaikutus, } \mathrm{k} \\
& \text { Eläin }=\text { satunnainen additiivinen eläintekijä, I } \\
& e_{\text {ijklm }}=\text { jäännöstekijä }
\end{aligned}
$$

Lehmä, eläin ja jäännöstekijä oletettiin normaalisti jakautuneiksi ja varianssi-kovarianssi matriisin rakenne oli $V_{(a)}=A \sigma^{2} a, V_{(c)}=I \sigma^{2} c, V_{(e)}=I \sigma^{2} e$ ja $\operatorname{cov}(a, e)=0$, jossa I identiteettimatriisi ja $A$ additiivinen geneettinen sukulaisuusmatriisi.

Varianssikomponenteista laskettiin eläinkohtaisen pysyvän ympäristövarianssin osuus kokonaisvarianssista $\left(\mathrm{c}^{2}\right)$ ja periytymisaste $\left(\mathrm{h}^{2}\right)$ keskivirheineen (SE). 


\section{TULOKSET JA TULOSTEN TARKASTELU}

Muuttujien $\mathrm{ME}_{\mathrm{m}}$ ja $\mathrm{k}_{1} \mathrm{c}^{2}$ ja $\mathrm{h}^{2}$ estimaatit eivät eronneet nollasta (Taulukko 1). Samaan metaboliokammioaineistoon pohjautuen tehdyssä rotuvertailussa (holstein-friisiläisiä ja holsteinfriisiläisristeytyksiä) ei havaittu MEm ja kl eroja puhtaiden ja risteytysten välillä (Dong et al. 2014), mikä tukee käsitystä, ettei selviä geneettistä vaihtelua näiden muuttujien osalta ole.

Sekä ECE:n $(0,09 \pm 0,04)$ että LWT:n $(0,25 \pm 0,23) c^{2}$ poikkesi tilastollisesti merkitsevästi nollasta. ECE:ssä $(0,05 \pm 0,09)$ näytti olevan viitteitä perinnöllisestä vaihtelusta vaikkakaan $\mathrm{h}^{2}$ poikennut tilastollisesti nollasta. Kirjallisuudessa on havaintoja, että ECE periytyy keskinkertaisesti ja lypsykauden alussa ja lopussa $\mathrm{h}^{2}$ estimaatit ovat korkeammat kuin keskivaiheilla (Liinamo et al. 2015).

Myös vertailuominaisuutena olleen LWT:n $(0,50 \pm 0,23) \mathrm{h}^{2}$ poikkesi tilastollisesti nollasta. Ominaisuudelle on saatu kirjallisuudessa samaa suuruusluokkaa olevia estimaatteja (Muller et al. 2006.

Taulukko 1, Varianssikomponenteista laskettiin eläinkohtaisen pysyvän ympäristövarianssin osuus kokonaisvarianssista $\left(\mathrm{c}^{2}\right)$ ja periytymisaste $\left(\mathrm{h}^{2}\right)$ keskivirheineen (SE).

\begin{tabular}{|l|l|l|l|l|}
\hline Muuttuja & $\mathbf{c}^{2}$ & $\mathbf{c}^{2} \mathbf{S E}$ & $\mathbf{h}^{2}$ & $\mathbf{h}^{2} \mathbf{S E}$ \\
\hline $\mathrm{ME}_{\mathrm{m}}$ & 0,00 & 0,00 & 0,00 & 0,09 \\
\hline $\mathrm{k}_{1}$ & 0,00 & 0,00 & 0,00 & 0,10 \\
\hline ECE & 0,09 & 0,04 & 0,05 & 0,09 \\
\hline LWT & 0,26 & 0,23 & 0,50 & 0,23 \\
\hline
\end{tabular}

\section{JOHTOPÄÄTÖKSET}

Vaikka aineisto oli laajuudeltaan huomattava lehmien energiametaboliatutkimuksen alalla, oli eläinmäärä liian pieni varianssikomponenttien luotettavaan estimointiin varsinkin heikosti periytyvissä ominaisuuksissa. Tämän aineiston perusteella ei muuntokelpoisen energian tarpeessa ylläpitoon tai energian käytön tehokkuudessa maidontuotantoon ilmennyt perinnöllistä vaihtelua, joka tarkoittaa ettei näiden ominaisuuksien kehittäminen jalostusvalinnalla olisi mahdollista. Energiakorjatun maidon tuotannossa muuntokelpoisen energian syöntiä kohden näytti kuitenkin olevan viitteitä perinnöllisestä vaihtelusta.

\section{KIRJALLISUUS}

Agricultural and Food Research Council (AFRC). 1993. Energy and protein requirements ofruminants. CAB International, Wallingford, Oxon, United Kingdom.

Dong, L., Yan, T. Ferris C.P.\& McDowell, D.A. 2014. Comparison of maintenance energy requirement and energetic efficiency between lactating Holstein-Friesian and other groups of dairy cows. Journal of Dairy Science 98(2).

Muller, C.J.C., Cloete, S.W.P., Olivier J.J., Botha J.A \& de Waal H. 2006. Heritability of live weight and condition score in a Holstein herd and correlations with milk traits - preliminary estimates. SASAS 36 (2).

Jensen J. and Madsen P. 2013. A user guide to DMU. A package for analysingmultivariate mixed models. Version 6, release 5.2. National Institute of Animal Science, Tjele, Denmark

Liinamo, A.-E.; Mäntysaari, P.; Lidauer, M. H.; \& Mäntysaari, E. A. 2015 Genetic parameters for residual energy intake and energy conversion efficiency in Nordic Red dairy cattle Acta Agriculturae Scandinavica, Section A - Animal Science 